\title{
PERATURAN DAERAH SYARIAH DALAM BINGKAI OTONOMI DAERAH
}

\author{
Alwi Bik \\ Pemerintah Kabupaten Pamekasan JI. Kabupaten No. 107 Pamekasan Madura | \\ mr.deangell I@gmail.com
}

\begin{abstract}
The authority in making the Regional Regulation (Perda) is a tangible manifestation of the application of the widely autonomy owned by a certain region. As a country that adheres to the principle of legality in each preparation and formation of legislation, the definition of regional authority in the preparation and establishment of local regulations must refer to the existing statutory provisions, especially those which govern the relationship between the central and the region in the Unitary of the Republic of Indonesia. Study on the existence of the Syariah Regional Regulation is a topic of the discussion that characterizes the dynamics of science, especially after the reform in Indonesia. The standpoint of most of the discussions about the existence of the Syari'ah Regional Regulation is quite varied, among others are: (a) from a legal standpoint, namely Law No. 10 year 2004 about the establishment of laws and regulations; (b) from a political standpoint; (c) from a social standpoint, and; (d) assessment of the investment point of view. From some of these studies, public policy should be any more emphasis on the benefit aspects of society. It is based on the legal maxim "policy of a top leader to his people always leads to a benefit".
\end{abstract}

Keywords: Regional regulation, shari'ah, regional autonomy.

Abstrak: Kewenangan dalam membuat Peraturan Daerah (PERDA), merupakan wujud nyata pelaksanaan hak otonomi secara luas yang dimiliki oleh suatu daerah. Sebagai sebuah negara yang menganut asas legalitas dalam setiap penyusunan dan pembentukan peraturan perundang-undangan, maka batasan kewenangan daerah dalam penyusunan dan pembentukan produk hukum daerah, haruslah merujuk pada ketentuan perundang-undangan yang ada, khususnya yang mengatur tentang hubungan pusat dan daerah dalam Negara Kesatuan Republik Indonesi. Kajian tentang keberadaan PERDA 
syariah, merupakan topik bahasan yang mewarnai dinamika keilmuan, khususnya setelah terjadinya reformasi di Indonesia. Sudut pandang sebagian besar pembahasan tentang keberadaan PERDA syariah cukup variatif, antara lain: a. Kajian dari sudut pandang hukum, yakni Undangundang Nomor 10 Tahun 2004 tentang Pembentukan Peraturan Perundang-Undangan, b. Kajian dari sudut pandang politis, c. Kajian dari sudut pandang sosial, dan d. Kajian dari sudut pandang investasi. Dari beberapa kajian tersebut, seyogyanya setiap kebijakan publik lebih ditekankan pada aspek-aspek kemanfaatan bagi masyarakat, berdasarkan kaidah fiqh "Kebijakan seorang pemimpin atas rakyatnya, senantiasa mengarah pada kemaslahatan".

Kata Kunci: PERDA, syariah, otonomi daerah.

\section{Pendahuluan}

Sejak rezim orde baru tumbang dan diganti dengan reformasi, maka paradigma konfigurasi politik mengalami perubahan cukup drastis dengan diberlakukannya otonomoi daerah yang seluasluasnya.

Paradigma "posotivistik-kuantitatif" yang dianut pemerintah orde baru sebagaimana tertuang di dalam UU Nomor 5 Tahun 1974 sebagai instrumen otoriterisme pemerintah pusat yang cenderung mengasumsikan warganya sebagai seragam dan statis atau sekedar angka-angka, turut pula menyebabkan terjadinya konflik vertikal antara pemerintah dengan masyarakat setempat. ${ }^{1}$ Pemerintah mengira bahwa aspirasi (politik, budaya ekonomi) masyarakat sama saja dimana-mana di Indonesia. Misalnya, harus sama seperti di Jawa, sehingga dalam penyusunan peraturan perundang-undangan, biasanya negara dengan hegemoninya cenderung berkehendak untuk memberlakukan hukum yang sama bagi setiap warga negaranya. ${ }^{2}$ Rancang bangun hukum nasional yang berporos pada politik kodifikasi dan unifikasi, telah berhasil menciptakan bangunan hukum berciri modern. Tapi tentulah kemoderenan sistem hukum itu, bukan tanpa masalah. Sebaliknya,

' Deddy Mulyana, Metodologi Penelitian Kualitatif, (Bandung: Rosda: 20 I I), x-xi.

${ }^{2}$ lbid., xi 
bangunan hukum yang bertopang pada politik kodifikasi dan unifikasi itu, membungkus persoalaan tersendiri pada arah praksis, khususnya dalam konteks komunitas lokal dengan keunikan dan pluralitasnya. ${ }^{3}$

Pemberlakuan otonomi daerah ditandai dengan disahkannya Undang-undang Nomor 22 Tahun 1999 tentang Pemerintahan Daerah. Undang-undang tersebut merupakan wujud dari paradigma yang dianut pada era reformasi yang sangat berbeda dengan paradigma di masa orde baru yang melahirkan patronase dengan sistemnya yang sentralistik dengan penekanan pada aspek stabilitas, integrasi, dan pengendalian secara sentralistik melalui perencanaan terpusat, sehingga menimbulkan kebijakan penyeragaman dan patronase politik yang mematikan kreativitas daerah. ${ }^{4}$ Lebih jauh, Moh, Mahfud MD menjelaskan bahwa paradigma dengan visi tersebut kemudian dijalin dalam sebuah interaksi visi di bidang politik, ekonomi dan sosial budaya dengan gambaran sebagai berikut :

1. Di bidang politik, munculnya kepala daerah yang dipilih secara demokratis, lahirnya pemerintah daerah yang responsif atas tuntutan masyarakat, lahirnya keputusankeputusan yang bertanggung jawab, adanya transparansi kebijakan, adanya struktur pemerintahan yang sesuai kebutuhan daerah, adanya sistem dan pola karier yang kompetitif, adanya manajemen pemerintahan yang efektif dan objektif.

2. Di bidang ekonomi, menjamin lancarnya ekonomi nasional di daerah, sekaligus memberi kesempatan bagi daerah untuk membuat kebijakan ekonominya sendiri.

\footnotetext{
${ }^{3}$ Bernard L. Tanya, Hukum dalam Ruang Sosial(Yogyakarta: Genta Publishing, 2010 ), 2.

4 Moh. Mahfud MD, Membangun Politik Hukum, Menegakkan Konstitusi, (Jakarta: PT. Rajagrafindo Persada, 2010), 222.
} 
3. Di bidang sosial dan budaya, membangun harmoni sosial sekaligus memelihara nilai-nilai lokal yang dianggap kondusif. ${ }^{5}$

Undang-Undang tersebut kemudian diubah dan disempurnakan dengan Undang-Undang Nomor 32 Tahun 2004 tentang Pemerintahan Daerah. Namun demikian, paradigma UU yang terakhir ini secara umum tetap relevan dengan paradigma UU Nomor 22 Tahun 1999 yang telah ikut mendorong terjadinya berbagai perubahan paradigma mendasar di daerah, yakni pola pemerintahan telah berubah dari yang sentralistik menjadi desentralistik disertai munculnya harapan akan suburnya iklim demokrasi di daerah. Iklim demokrasi yang dikaitkan dengan penyelenggaraan pemerintahan yang baik atau sistem politik yang ideal yang selaras dengan gaya hidup serta tata masyarakat tertentu yang mengandung unsur-unsur moral, khususnya yang berkaitan dengan pembentukan/penyusunan peraturan daerah, atau meminjam istilah Jimly Asshiddiqie yang menyamakan peraturan daerah dengan 'undang-undang lokal' atau locale wet (local legislation) yakni peraturan yang dibentuk oleh lembaga legislatif lokal dengan kekuatan berlaku hanya dalam lingkup wilayah satuan pemerintah lokal. ${ }^{6}$ Dalam pandangan R.Siti Zuhro, Undang-undang Nomor 32 Tahun 2004 tentang Pemerintahan Daerah merupakan lompatan demokrasi yang cukup penting dalam lanskap sosio-politik Indonesia, dari yang bercorak sentralistik dimasa orde baru, menjadi desentralistik di era reformasi.7

Akhir dari sedimentasi kearifan lokal ini akan mewujud menjadi tradisi atau agama yang melekat dalam kehidupan seharihari. Kearifan lokal biasanya tercermin dalam kebiasan-kebiasan hidup masyarakat yang telah berlangsung lama. Keberlangsungan

\footnotetext{
${ }^{5}$ Ibid., 233.

${ }^{6}$ Jimly Asshiddiqie, Perihal Undang-undang, (Jakarta: Konstitusi Press, 2006), 24.

7 R.Siti Zuhro, dkk, Demokrasi Lokal, Perubahan dan Kesinambungan Nilai-Nilai Budaya Politik Lokal, (Yogyakarta: Ombak, 2009), 48
} 
kearifan lokal akan tercermin pada nilai-nilai yang berlaku dalam kelompok masyarakat tertentu. Nilai-nilai itu menjadi pegangan kelompok masyarakat tertentu yang biasanya akan menjadi bagian hidup tak terpisahkan yang dapat diamati melalui sikap dan perilaku mereka sehari-hari. ${ }^{8}$

Dengan prinsip "berdasarkan aspirasi masyarakat" tersebut, maka Undang-Undang Nomor 32 Tahun 2004 tentang Pemerintahan Daerah, telah memberikan jalan bagi interaksi politik demokratis dalam legislasi ${ }^{9}$ PERDA. Dimana dalam hazanah ilmu hukum, "legislasi" mengandung makna dikotomis yang berarti; (1) proses pembentukan hukum, dan juga bisa berarti, (2) produk hukum. ${ }^{10}$

Dalam penjelasan Undang-Undang Nomor 32 Tahun 2004 tentang Pemerintahan Daerah, ditegaskan bahwa prinsip pemberian otonomi luas kepada daerah diarahkan untuk mempercepat terwujudnya kesejahteraan masyarakat melalui peningkatan pelayanan, pemberdayaan dan peran serta masyarakat. Seiring dengan prinsip itu, penyelenggaraan otonomi daerah harus selalu berorientasi pada peningkatan kesejahteraan masyarakat dengan selalu memperhatikan kepentingan dan aspirasi yang tumbuh dalam masyarakat.

Pembentukan PERDA yang berdasarkan "kepentingan dan aspirasi yang tumbuh dalam masyarakat", paralel dengan pendapat Eugene Ehrlich, salah satu pemikir hukum dalam persepektif sosiologis, yang menyatakan bahwa hukum yang baik haruslah sesuai dengan hukum yang hidup di masyarakat. ${ }^{11}$ Ia menambahkan pula bahwa hukum positif baru akan memiliki daya berlaku yang efektif jika berisikan atau selaras dengan

8 Teeri, Marchettini, dan Rosini. http:/library.witpress.com/pages/paperinfo.asp,akses tanggal 29 Mei 2009.

9 Dalam studi ini "legislasi" dimaknai sebagai proses pembentukan hukum dalam rangka melahirkan hukum positif dalam arti hukum perundang-undangan/peraturan perundangundangan.

${ }^{10}$ Andang L. Binawan, Menurut Logika Legislasi (2005) sebagaimana dikutip Anis Ibrahim, Legislasi dan Demokrasi, (Malang: In-Trans Publishing, 2008), I.

I' Sajipto Rahardjo, Hukum dan Masyarakat, (Bandung: Angkasa, 1984), 20.

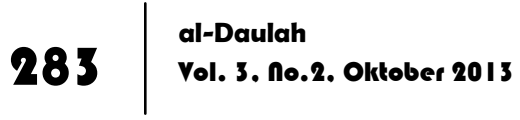


hukum yang hidup dalam masyarakat (the living law). Menurut pemikiran Ehrlich, mereka yang berperan sebagai pihak yang mengembangkan hukum harus mempunyai hubungan yang erat dengan nilai-nilai ${ }^{12}$ yang dianut dalam masyarakat bersangkutan. ${ }^{13}$

Partisipasi masyarakat dalam pembentukan hukum dapat ditemukan dalam Undang-Undang Nomor 10 Tahun 2004 tentang Pembentukan Peraturan Perundang-Undangan, pada pasal 53 disebutkan bahwa "Masyarakat berhak memberikan masukan secara lisan atau tertulis dalam rangka penyiapan atau pembahasan rancangan undang-undang dan rancangan peraturan daerah". Ini berarti bahwa bila masyarakat menghendaki, maka hukum (yang sarat dengan muatan nilai-nilai agama dan adat) dapat diajukan menjadi rancangan undang-undang maupun peraturan daerah.

Namun demikian, meskipun terdapat interaksi yang kuat antara hukum dan politik, sebagaimana dalam pandangan Sajipto Rahardjo bahwa politik memiliki konsentrasi energi yang lebih besar, sehingga hukum selalu berada pada posisi yang lemah. ${ }^{14}$ Melihat kenyataan demikian, maka kerapkali otonomi hukum berada di bawah tekanan politik, bukan saja proses pembuatanya, melainkan pula pada implementasi penerapan hukumnya.

Seiring dengan perjalanan waktu, eksistensi hukum Islam masuk ke dalam wadah normatif adalah merupakan kebutuhan masyarakat Indonesia dan bukan lagi karena nuansa mayoritas dan monoritas. Menurut Soehartono, gejala transformasi yang demikian lahir dari kesadaran yang tinggi dari masyarakat Indonesi. Hukum yag timbul dari kesadaran masyarakat, berarti hukum tersebut timbul sebagai cerminan hukum

\footnotetext{
12 Sebuah setting kehidupan yang sudah terbentuk secara langsung akan memproduksi nilai-nila. Nilai-nilai tersebut yang akan menjadi landasan hubungan mereka atau menjadi acuan tingkah laku mereka. Lihat Sarlito Wirawan, Psikologi Lingkungan, (Jakarta: Grasindo, 1992), 6.

13 Anis Ibrahim, Legislasi dan Demokrasi, I I.

14 Sajipto Rahardjo, Beberapa Pemikiran tentang Ancangan antar Disiplin dalam Pembinaan Hukum Nasional, (Bandung: Sinar Baru, 1985), 71.
} 
rakyat/mencerminkan hukum rakyat yang hidup dan dianut oleh rakyat setempat dalam kehidupan sehari-hari. ${ }^{15}$

Dari beberapa pilihan strategis, antara lain melalui gerakan individu, gerakan sosial dan pendidikan, gerakan sosial politik, gerakan legislasi, dan gerakan konstitusi dalam konstitusi, yang dapat dilakukan dalam pemberlakuan hukum Islam, maka gerakan legislasi melalui pemberlakuan peraturan daerah yang berlandaskan syariah (hukum agama), yang dalam konteks ini adalah hukum Islam atau yang lebih dikenal dengan sebutan PERDA syariah.

\section{Kerangka Teoritik}

Kerangka teoritik yang digunakan sebagai pendekatan dalam kajian ini adalah teori utilitas (kemanfaatan) Jeremy Bentham, di dalam karyanya yang berjudul Introduction to the Princples of Morals and Legislation, yang melahirkan sebuah agadium "the greatest happines for the greatest number" yang artinya, "kebahagian yang terbesar untuk jumlah yang terbanyak". Dengan demikian, hukum harus mengusahakan kebahagiaan maksimum bagi sebanyak mungkin orang. ${ }^{16}$ Hak-hak individu harus berada di bawah kebutuhan-kebutuhan masyarakat, merupakan standar etik dan yuridis dalam kehidupan sosial. Dari sinilah Bentham menghubungkan hak-hak individu dengan kebutuhan-kebutuhan orang lain, dengan demikian, hukum diorientasikan pada kegunaanya, yaitu memberikan kebahagiaan yang sebesarbesarnya sebagaimana prinsip yang dikemukakannya. ${ }^{17}$

Senada dengan pengertian di atas, Sabian Utsman ${ }^{18}$ mengutip pendapat Rudolph Von Ihering (1818-1892) seorang tokoh

15 Soehartono, "Gejala Transformasi Hukum Islam dalam hukum Nasional Majalah Hukum Yustisia Fakultas Hukum Universitas Sebelas Maret, No. 64 tahun XVI, (Januari-Maret 2004), 753.

${ }^{16}$ Green Mind Community, Teori dan Politik Hukum Tata Negara, (Yogyakarta: Total Media, 2009), 342.

17 Ibid., 343.

18 Sabian Utsman, Dasar-Dasar Sosiologi Hukum Makna Dialog antara Hukum \& Masyarakat, (Yogyakarta: Pustaka Pelajar, 2009), 153. 
utilitarianisme: "Hukum sebagai sarana untuk mengendalikan individu-individu agar tujuannya sesuai dengan tujuan masyarakat dimana mereka menjadi warganya....hukum juga merupakan suatu alat yang dapat digunakan untuk melakukan perubahan-perubahan sosial. ${ }^{19}$ Begitu pula Irfan Ismail mengutip asumsi para ahli filosof utilitarian seperti Jeremy Bentham dan Jhon Stuart Mill, bahwa semua tingkah laku manusia bertujuan untuk "mencari kesenangan dan menghindari kesusahan". Nilai utilitas (kemanfaatan) sesuatu benda atau tindakan (perbuatan) itu harus dinilai berdasarkan pada perbedaan antara kesenangan yang akan diperolehnya dan biaya (kesulitan) yang dikeluarkannya. ${ }^{20}$

Teori ini sejalan dengan tujuan hukum, sebagaimana dikemukakan Sidharta bahwa berbicara tentang tujuan hukum berarti berbicara mengenai nilai-nilai dasar hukum. Seperti dinyatakan oleh Radbruch, bahwa sesuatu yang dibuat pasti memiliki cita atau tujuan. Jadi tujuan hukum dibuat pun ada tujuannya. Tujuan ini merupakan nilai yang ingin diwujudkan manusia. Tujuan hukum yang utama ada tiga, yaitu :

a. Keadilan, mengandung makna bahwa hukum mengabdi pada kepentingan umum, bukan kepentingan individu tertentu saja;

b. Kepastian, mengandung makna kepastian orientasi, yaitu kejelasan rumusan norma yang diatur, sehingga dapat dijadikan pedoman bagi masyarakat yang dikenakan peraturan itu;

c. Kemanfaatan, mengandung makna bahwa nilai kemanfaatan dalam norma hukum sangat berguna, khususnya dalam norma hukum yang bersifat mengatur. Masyarakat akan mentaati hukum, tanpa perlu dipaksa dengan sanksi, apabila memang masyarakat merasakan manfaat dari kepatuhan tersebut. $^{21}$

\footnotetext{
${ }^{19} \mathrm{lbid}$.

${ }^{20}$ Irfan Ismail, Prinsip-prinsip Perumusan Kebijaksanaan Negara Cet. XV, Jakarta: Bumi Aksara, 2009), 48.

21 Sidharta, Moralis Profesi Hukum Suatu Tawaran Kerangka Berpikir, (Bandung: PT Refika Aditama, 2006), 79-86.
} 
Penganut aliran utilitarianisme bersikeras bahwa tujuan hukum satu-satunya adalah untuk mencapai kemanfaatan ini. Hukum yang baik adalah hukum yang membawa kemanfaatan bagi manusia. Kemanfaatan disini dapat juga diartikan dengan kebahagiaan (happines). Jadi, baik buruknya suatu hukum bergantung pada apakah hukum itu memberikan kebahagiaan atau tidak bagi manusia. ${ }^{22}$

Teori utilitarianisme menempatkan "prinsip manfaat" sebagai norma yang mana suatu konsep keadilan bisa bertumpu dan dikembangkan. Karena prefensinya untuk memberikan manfaat yang paling besar bagi sebanyak mungkin anggota masyarakat, ${ }^{23}$ maka teori ini cenderung menganggap bahwa sebagai individu yang menjadi patokan untuk mengukur tingkat kesejahteraan manusia dari ukuran yang berpedoman pada tingkat kesejahteraan individu kepada ukuran yang berpatokan kepada kesejahteraan masyarakat secara keseluruhan. ${ }^{24}$

Utilitarianisme melihat keinginan individu-individu hanya sebagai bagian dari keinginan keseluruhan masyarakat, sehingga ketika keinginan seluruh masyarakat telah tercapai..$^{25}$

Lebih lanjut Sidharta menjelaskan bahwa nilai kemanfaatan bersinggungan langsung dengan kepentingan setiap subjek hukum. Norma hukum menekankan perlindungan terhadap kepentingan dari subjek hukum yang kedudukannya paling lemah. Larangan membunuh tidak ditujukan untuk kepentingan si (calon) pembunuh agar ia berakhlak baik, tetapi terutama diarahkan bagi kepentingan si (calon) korban pembunuhan agar jiwanya terlindungi dan dihargai. ${ }^{26}$

Dalam formulasi hukum Islam, metode utilitas ini lebih dikenal dengan penalaran istislahiy, yang menetapkan hukum berdasarkan istislah ( kemaslahatan), yang dalam teori utilitas

\footnotetext{
${ }^{22}$ Ibid., 86.

23 Moh. Dahlan, Epistimologi Hukum Islam, (Yogyakarta: Pustaka Pelajar, 2009), 174.

${ }^{24}$ Ibid., 174- 175.

${ }^{25} \mathrm{lbid} ., 175$.

${ }^{26}$ Sidharta, Moralitas Profesi Hukum, 86.
} 
dikenal dengan istilah kesejahteraan, dengan sasaran utamanya pada kesejahteraan masyarakat, atau dalam formulasi hukum Islam dikenal dengan istilah maslahah' ammah. Cara kerja istislah ini digunakan untuk menjawab berbagai persoalan hukum yang berkembang seiring perubahan dan pergerakan yang dialami manusia.

Abu Ishaq al-Shatibi (w. 790H/1388 M) merinci metode istislah ini dalam karya monumentalnya al-Muwafaqat fi Usul al-Shari'ah, ia mengemukakan bahwa para ulama selama ini hanya memutuskan hukum semata-mata bertumpu pada istinbat hukum berdasar pada aspek kebahagiaan saja (sebatas pada pencarian illat hukum pada waktu melakukan qiyas), dengan melupakan aspek tujuan syariah (maqasid al-shari'ah). Mengingat ide dasar dari penetapan suatu hukum haruslah bertumpu pada prinsip kemaslahatan bagi manusia, baik di dunia maupun di akhirat. ${ }^{27}$

\section{Keberlakuan Hukum Islam di Indonesia}

Membicarakan teori pemberlakuan hukum Islam akan sangat berkaitan dengan proses bagaimana unsur-unsur hukum Islam itu dapat menjadi hukum positif atau bagian dari hukum nasional, disamping hukum adat dan hukum barat. Politisasi hukum yang dilakukan oleh kolonial Belanda kearah mereduksi syariat Islam serta menjauhkan dari masyarakatnya, menyebabkan hukum Islam saat ini terpinggirkan proses positivisasi hukum dalam perspektif tata hukum Indonesia. ${ }^{28}$

1. Teori receptio incomplexu. Teori ini dikemukakan oleh Lodewijk Willem Christian Van den Berg (1854-1927)29 bahwa bagi orang Islam berlaku penuh hukum Islam, sebab mereka

27 Abu Ishaq al-Shatibi, al-Muwafaqat fi Usul al-Shari'ah, (Berut: Dar al-Kutub al-'llmiyayah, II, 2002), 5.

28 A. Rahmat Rosyadi dan H.M. Rais Ahmad, Formalisasi Syariat Islam dalam Perspektif Tata Hukum Indonesia, (Bogor: Ghalia Indonesoa, 2006), 68.

${ }^{29}$ Van der Berg ketika itu menjabat sebagai petugas kebahasan dan penasehat dalam bahasabahasa Timur dan hukum Islam. Lihat Sirajuddin, Legislasi Hukum, 80. 
telah memeluk agama Islam walaupun dalam pelaksanaanya terdapat penyimpangan-penyimpangan..$^{30}$

2. Teori resepsi (receptie theory). Snouck secara umum berpendapat bahwa hukum Islam yang sudah berlaku di masyarakat sudah tidak bisa disebut hukum Islam sebab telah terjadi penerimaan dari masyarakat, sehingga dijadikan kebiasaan sehari-hari. Eksistensi teori receptie ini kemudian dikokohkan melalui pasal 134 I.S yang menyatakan bahwa bagi orang pribumi kalau hukum mereka menghendaki, diberlakukan hukum Islam selama hukum itu telah diterima oleh masyarakat hukum adat. ${ }^{31}$

3. Teori receptie exit. ${ }^{32}$ Berdasarkan teori Hazairin ini dapat dinyatakan:

a. Teori receptie telah patah, tidak berlaku dan exit dari tata negara Indonesia sejak tahun 1945 dengan kemerdekaan bangsa Indonesia dan mulai berlakunya UUD 19945 dan Dasar Negara Indonesia, demikian pula keadaan ini setelah adanya Dekrit Presiden tanggal 5 Juli 1959 untuk kembali kepada UUD 1945;

b. Sesuai dengan Pasal 29 ayat (1) UUD 1945, Negara Republilk Indonesia berkewajiban membentuk hukum nasional Indonesia yang bahan bakunya adalah hukum agama;

c. Hukum agama yang masuk dan menjadi hukum nasional Indonesia itu bukan hanya hukum Islam saja, melainkan juga hukum agama lain untuk pemeluk agama lain tersebut. Hukum perdata dan hukum pidana diserap menjadi hukum nasional. Itulah hukum baru Indonesia dengan dasar Pancasila. ${ }^{33}$

30 Ichtijanto,SA, "Pengembangan Teori Berlakunya Hukum Islam di Indonesia", dalam Eddi Rusdiana Arief dkk. Hukum Islam di Indonesia, (Jakarta: Rosdakarya, 1994), 177.

${ }^{31}$ Afdol, Legislasi Hukum Islam di Indonesia, (Surabaya: Airlangga University Press, 2006) 47.

32 Afdol,Legislasi hukum, 50, Lihat pula Dedi Supriyadi, Sejarah Hukum Islam, 316.

33 Ichtijanto, Hukum Islam, I31, Afdol, Legislatif Hukum Islam, 5 I dan Dedi Supriyadi, Sejarah Hukum Islam, 316. 
Sejalan dengan pendapat Hazairin, Daud Ali mengatakan bahwa sejak lahirnya UU No. 1 Tahun 1974 tentang Perkawinan, maka:

a. Hukum Islam menjadi sumber hukum yang langsung tanpa harus melallui hukum adat dalam menilai apakah perkawinan itu sah atau tidak;

b. Hukum Islam sama kedudukannya dengan hukum adat dan hukum barat;

c. Negara Republlik Indonesia dapat mengatur suatu maslah sesuai dengan hukum Islam sepanjang pengaturan itu untuk memenuhi kebutuhan hukum umat Islam. ${ }^{34}$

4. Teori receptio a contrario

Pada perkembangan berikutnya, Sayuti Thalib (salah seorang murid Hazairin dan juga dosen Fakultas Hukum UI) mengintroduksi sebuah teori baru yang bernama receptio a contrario, yang berarti "bahwa hukum adat baru berlaku apabila diterima oleh hukum Islam, hukum Islam baru berlaku apabila berdasarkan al-Qur'an hukum adat bersendi shara', shara' bersendi kitabullah). ${ }^{35}$ Teori receptio a contrario ini merupakan kelanjutan dalam menerjemahkan dan menjelaskan pemikiran Hazairin yang didukung oleh hasil penelitian lapangan di masyarakat. Yaitu, di beberapa masyarakat muslim telah terjadi perubahan dimana hukum adat yang ada akan diterima kalau sesuai dengan hukum Islam. ${ }^{36}$

\footnotetext{
${ }^{34}$ Abdul Ghofur Anshori dan Yulkarnain Harahab, Hukum Islam Dinamika dan Perkembangannya di Indonesia, (Yogyakarta: Kreasi Total Media, 2008), I 12.

35 Muhammad Idris Ramulyo, Asas-asas Hukum Islam: Sejarah Timbul dan Berkembangnya Hukum Islam dalam Sistem Hukum di Indonesia, (Jakarta: Sinar Grafika. 1995), 58-59.

${ }^{36}$ A. Qodri A. Azizy, Eklektisisme Hukum Nasional, Kompetisi Antara Hukum Islam dan Hukum Umum, (Yogyakarta: Gama Media,2002), 160.
} 


\section{Kewenangan dalam Membuat PERDA}

Kewenangan dalam membuat peraturan daerah merupakan wujud nyata pelaksanaan hak otonomi secara luas yang dimiliki oleh suatu daerah. ${ }^{37}$ Karena pada hakikatnya, peraturan daerah merupakan keputusan dalam arti luas, sebagai tujuan untuk mengatur hidup bersama, melindungi hak dan kewajiban manusia dalam masyarakat, melindungi lembaga-lembaga sosial dalam masyarakat, dan menjaga keselamatan serta tata tertib masyarakat di daerah yang bersangkutan dan kesejahteraan umum.

Sebagai sebuah negara yang menganut asas legalitas ${ }^{38}$ dalam setiap penyusunan dan pembentukan peraturan perundangundangan, maka batasan kewenangan daerah dalam penyusunan dan pembentukan produk hukum daerah, haruslah merujuk pada ketentuan perundang-undangan yang ada, khususnya yang mengatur tentang hubungan pusat dan daerah dalam Negara Kesatuan Republik Indonesi. Sehingga kewenangan akibat pemberian kesempatan dan kekuasaan bagi daerah untuk mengatur dan mengurus rumah tangganya sendiri tidak disalahartikan maupun disalahgunakan, maka kewenangan tersebut haruslah diatur dan dibatasi oleh undang-undang, sesuai pasal 1 ayat (3) Undang-Undang Dasar Negara Republik Indonesia tahun 1945 menetapkan bahwa Negara Indonesia adalah negara hukum. Dengan demikian, seluruh aspek kehidupan kemasyarakatan, khususnya dalam rangka penyelenggaraan pemerintahan daerah (hubungan antara pemerintahan daerah dan

\footnotetext{
${ }^{37}$ Rozali Abdullah, Pelaksanaan Otonomi Luas dengan Pemilihan Kepala Desa Secara Langsung, (Jakarta: Raja Grafinda Persada, 2005), I3I.

${ }^{38}$ Ide dasar rechtsstat didasarkan pada syarat-syarat yang terdiri atas: (I) asa legalitas, yakni setiap tindakan pemerintahan harus didasarkan atas dasar peraturan perundang-undangan, (2) pembagian kekuasaan, yakni kekuasaan Negara tidak boleh hanya bertumpu pada satu tangan saja, (3) hak-hak dasar, yakni sasaran perlindungan hukum bagi rakyat dan sekaligus membatasi kekuasaan pembentukan undang-undang, (4) pengawasan pengadilan, yaknitersedianya saluran bagi rakyat melalui pengadilan yang bebas untuk menguji keabsahan tindakan pemerintahan. Lihat Phillipus M.Hardjon, Ide Negara Hukum dalam Sistem Ketatanegaraan Indonesia, dalam Bagir Manan (ed). Kedaulatan Rakyat, Hak Asasi Manusia dan Negara Hukum, (Jakarta: Gaya Media Pratama, 1996), 78-79.
} 
masyarakatnya), serta dalam hubungan antar sesama warga masyarakatnya), serta dalam hubungan antar sesama warga masyarakat di daerah harus berlandaskan peraturan daerah.

\section{Materi Muatan dan Asas Produk Hukum Daerah}

Materi muatan Peraturan Perundang-undangan adalah materi yang dimuat dalam Peraturan Perundang-undangan sesuai jenis, fungsi dan hirarki ${ }^{39}$ Perauran Perundang-undangan (Bab I Ketentuan Umum UU Nomor 10 Tahun 2004). Sedang materi muatan yang secara spesifik terkait dengan peraturan daerah, tertuang dalam pasal 12 UU Nomor 10 Tahun 2004 menyebutkan "Materi Muatan Peraturan Daerah adalah seluruh materi muatan dalam rangka penyelenggaraan otonomi daerah ${ }^{40}$ dan tugas pembantuan, ${ }^{41}$ dan menampung kondisi khusus daerah serta penjabaran lebih lanjut Peraturan Perundang-undangan yang lebih tinggi". Pasal tersebut memberikan pemahaman bahwa materi muatan peraturan daerah dimaksudkan:

1. Perundang-undangan dalam rangka penyelenggaraan otonomi daerah dan tugas pembantuan;

2. Menampung kondisi daerah;

3. Penjabaran peraturan perundang-undangan yang lebih tinggi.

Sejalan dengan ketentuan di atas, pada Pasal 136 ayat (3) UU Nomor 10 Tahun 2004 memberikan ruang lingkup materi muatan peraturan daerah sebagai penjabaran peraturan yang lebih tinggi dengan memperhatikan ciri khas masing-masing daerah. Sedang

${ }^{39}$ Yang dimaksud dengan hirarki adalah penjenjangan setiap jenis Peraturan Perundang-undangan yang didasarkan pada asas: bahwa Peraturan Perundang-undangan yang lebih rendah tidak boleh bertentangan dengan Peraturan Perundang-undangan yang lebih tinggi. (penjelasan UU No.32 Tahun 2004, Pasal 7 ayat (5).

40 Otonomi daerah adalah hak, wewenang, dan kewajiban daerah otonom untuk mengatur dan mengurus sendiri urusan pemerintahan dan kepentingan masyarakat setempat sesuai dengan Peraturan Perundang-undangan. Lihat Undang-Undang Nomor 32 Tahun 2004 Tentang Pemerintahan Daerah Bab I Ketentuan Umum Pasal I nomor 5,

4) Tugas Pembantuan adalah penugasan dari Pemerintah kepada daerah dan/atau desa, dari pemerintah provinsi kepada Kabupaten/Kota dan/atau desa, serta dari pemerintah kabupaten/kota kepada desa untuk melaksanakan tugas tertentu. ( Bab I Ketentuan Umum UU No. 32 Tahun 2004) 
pada ayat (4) dinyatakan bahwa peraturan daerah dilarang bertentangan dengan kepentingan umum dan atau peraturan yang lebih tinggi ${ }^{42}$. Materi muatan peraturan daerah adalah seluruh materi muatan dalam rangka penyelenggaraan otonomi daerah dan tugas pembantuan, yang menampung kondisi daerah serta penjabaran lebih lanjut peraturan perundang-undangan yang lebih tinggi (Pasal 12 UU Nomor 32 Tahun 2004). Apabila kita mencermati Undang-Undang Nomor 10 Tahun 2004 Tentang Pembentukan Peraturan Perundang-undangan, maka ditemukan beberapa asas yang harus dipenuhi dalam peraturan daerah terkait materi muatanya sebagaimana diatur pada Pasal 6 ayat (1) "Materi Muatan Peraturan Perundang-undangan mengandung asas:

a) Pengayoman, adalah bahwa setiap materi muatan peraturan perundang-undangan harus berfungsi memberikan perlindungan dalam rangka menciptakan ketentraman masyarakat; ${ }^{43}$

b) kemanusiaan, adalah bahwa setiap materi muatan peraturan perundang-undangan harus mencerminkan perlindungan dan penghormatan hak-hak asasi manusia serta harkat dan martabat setiap warga negara dan penduduk Indonesia secara proporsional. ;44

c) Kebangsaan, adalah bahwa setiap materi muatan peraturan perundang-undangan harus mencerminkan sifat dan watak bangsa indonesia yang pluralistik (kebhinnekaan) dengan tetap menjaga prinsip Negara Kesatuan Republik Indonesia;45

d) Kekeluargaan, adalah bahwa setiap materi muatan perundang-undangan harus mencerminkan musyawarah

42 Dalam konteks ini yang dimaksudkan dengan bertentangan dengan kepentingan umum adalah kebijakan yang mengakibatkan terganggunya kerukunan warga, terganggunya pelayanan umum, dan terganggunya ketertiban/ketenntraman masyarakat serta kebijakan /peraturan daerah yang bersifat dikriminatif. Lihat Penjelasan UU No. 32 Tahun 2004 pasal I 36 ayat (4).

${ }^{43}$ Penjelasan pasal 6 ayat (I) Huruf a,

${ }^{44}$ Penjelasan pasal 6 ayat ( 1 ) Huruf b,

${ }^{45}$ Penjelasan pasal 6 ayat (I) Huruf c, 
untuk mencapai mufakat dalam setiap pengambilan keputusan; 46

e) Kenusantaraan, adalah bahwa setiap materi muatan peraturan perundang-undangan harus senantiasa memperhatikan kepentingan seluruh wilayah Indonesia dan materi muatan Peraturan Perundang-undangan yang dibuat di daerah merupakan bagian dari sistem hukum nasional yang berdasarkan Pancasila; 47

f) Bhinneka tunggal ika, adalah bahwa materi muatan peraturan perundang-undangan harus memperhatikan keragaman penduduk, agama, suku dan golongan, kondisi khusus daerah, dan budaya, khususnya hukum yang menyangkut masalahmasalah senditif dalam kehidupan bermasyarakat, berbangsa dan bernegara; 48

g) Keadilan, adalah bahwa setiap materi muatan perturan perundang-undangan harus mencerminkan keadilan secara proposional bagi setiap warga negara tanpa kecuali; ${ }^{49}$

h) Kesamaam kedudukan dalam hukum dan pemerintahan, adalah bahwa setiap materi muatan peraturan perundangundangan tidak boleh berisi hal-hal yang bersifat membedakan berdasarkan latar belakang antara lain, agama, suku, ras, golongan, gender, atau status sosial;50

i) Ketertiban dan kepastian hukum, adalah bahwa setiap materi muatan peraturan perundang-undangan harus dapat menimbulkan ketertiban dalam masyarakat melalui jaminan adanya kepastian hukum; ${ }^{51}$ dan/atau

j) Keseimbangan, keserasian, dan keselarasan, adalah bahwa setiap materi muatan peraturan perundang-undangan harus mencerminkan keseimbangan, keserasian, dan keselarasan

\footnotetext{
${ }^{46}$ Penjelasan pasal 6 ayat (I) Huruf d,

${ }^{47}$ Penjelasan pasal 6 ayat (I) Huruf e,

${ }^{48}$ Penjelasan pasal 6 ayat (I) Huruf $\mathrm{f}$,

${ }^{49}$ Penjelasan pasal 6 ayat (I) Huruf g,

${ }^{50}$ Penjelasan pasal 6 ayat ( 1 ) Huruf $h$,

${ }^{51}$ Penjelasan pasal 6 ayat (I) Huruf i,
} 
antara kepentingan individu dan masyarakat dengan kepentingan bangsa dan negara. ${ }^{52}$

\section{Penutup}

Kajian tentang keberadaan PERDA syariah atau juga ada yang menyebutkan sebagai PERDA bermasalah atau bahkan ada pula yang menyebutkan sebagai PERDA yang kebablasaan, merupakan topik bahasan yang mewarnai dinamika keilmuan, khususnya setelah terjadinya reformasi di Indonesia. Sudut pandang sebagian besar pembahasan tentang keberadaan PERDA syariah tersebut cukup variatif, antara lain:

a. Kajian dari sudut pandang hukum yang memfokuskan pada pemahaman, penafsiran dan pengembangan aspek yuridis yang dimiliki daerah terkait dengan muatan materi sebagaimana diatur dalam undang-undang, yakni Undangundang Nomor 10 Tahun 2004, sehingga keberadaanya menimbulkan berbagai tanggapan para ahli yang sampai saat ini masih terdapat pro dan kontra dan belum ditemukan adanya titik temu.

b. Kajian dari sudut pandang politis yang lebih memfokuskan pada penonjolan aspek-aspek politis sesuai konfigurasi politik masing-masing daerah.

c. Kajian dari sudut pandang sosial. Kajian ini menyoroti terganggunya kebebasan masyarakat sipil yang dikaitkan dengan HAM, banyak PERDA syariah yang dianggap melanggar kebebasan hak-hak sipil, bias gender karena sebagian besar muatan materi PERDA syariah menjadikan kaum perempuan sebagai focus sentralnya, dan bersifat diskriminatif, yang pada akhirnya dimaknai melanggar hakhak asasi manusia. Karena itu munculnya istilah PERDA syariah sebagai PERDA bermasalah, datangnya dari kelompok -kelompok yang menghendaki adanya kebebasan sipil, yang

${ }^{52}$ Penjelasan pasal 6 ayat ( 1 ) Huruf $\mathrm{j}$, 
menganggap tidak ada perlunya pemerintah mengatur urusan keagamaan (ritualitas) setiap warga negara.

d. Kajian dari sudut pandang investasi

Kajian ini melihat dampak pemberlakuan PERDA syariah terhadap pertumbuhan dan perkembangan iklim investasi di daerah. Dalam hasil penelitian yang dilakukan sering kali keberadaan PERDA syariah menjadi salah satu hambatan bagi perkembangan, pertumbuhan dan perluasan iklim investasi di daerah, yang pada akhirnya mempersempit ruang gerak bagi penciptaan lapangan kerja.

Secara teroritis, kajian ini merupakan sebuah temuan baru yang sekaligus merupakan pengembangan dari beberapa penelitian dan kajian sebelumnya, yakni berusaha melakukan kajian keberadaan PERDA dari aspek kemanfaatannya. Dengan bertitik tolak dari sebuah kaidah dalam kajian ilmu keislaman bahwa:

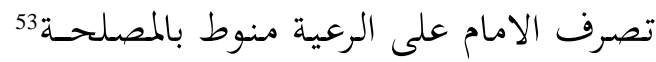

"Kebijakan seorang pemimpin atas rakyatnya, senantiasa mengarah pada kemaslahatan".

Maka seyogyanya setiap kebijakan publik dirumuskan tidak hanya terpaku pada term istilah yang diambil dari istilah-istilah agama, begitu pula tidak karena nuansa politis, agar menjadi terkenal dan mendapat sanjungan, namun lebih ditekankan pada aspek-aspek kemanfaatan bagi masyarakat yang dapat dikaji dari berbagai sudut pandang kehidupan kemasyarakatan.

${ }^{53}$ Jalal al-Din Abd al-Rahman al-Suyuti, al-Ashbah wa al-Nazaír, Cet I, ( Beirut: Muassasah alKutub al-Thaqafiyyyah, 1994 ), 158. 


\section{Daftar Pustaka}

Abdullah, Rozali. Pelaksanaan Otonomi Luas dengan Pemilihan Kepala Desa Secara Langsung. Jakarta: Raja Grafinda Persada, 2005.

Afdol. Legislasi Hukum Islam di Indonesia. Surabaya: Airlangga University Press, 2006.

Anshori, Abdul Ghofur dan Yulkarnain Harahab. Hukum Islam

Dinamika dan Perkembangannya di Indonesia. Yogyakarta: Kreasi Total Media, 2008.

Asshiddiqie, Jimly. Perihal Undang-undang. Jakarta: Konstitusi Press, 2006.

Azizy, A. Qodri. Eklektisisme Hukum Nasional, Kompetisi Antara Hukum Islam dan Hukum Umum. Yogyakarta: Gama Media, 2002.

Binawan, Andang L. Menurut Logika Legislasi (2005).

Dahlan, Moh. Epitimologi Hukum Islam. Yogyakarta: Pustaka Pelajar, 2009.

Green Mind Community. Teori dan Politik Hukum Tata Negara. Yogyakarta: Total Media, 2009.

Hardjon, Phillipus M. Ide Negara Hukum dalam Sistem Ketatanegaraan Indonesia. dalam Bagir Manan (ed). Kedaulatan

Rakyat, Hak Asasi Manusia dan Negara Hukum. Jakarta: Gaya Media Pratama, 1996.

Ibrahim, Anis. Legislasi dan Demokrasi. Malang: In-Trans Publishing, 2008.

Ichtijanto, SA. "Pengembangan Teori Berlakunya Hukum Islam di Indonesia", dalam Eddi Rusdiana Arief dkk. Hukum Islam di Indonesia. Jakarta: Rosdakarya, 1994.

Ismail, Irfan. Prinsip-prinsip Perumusan Kebijaksanaan Negara. Cet. XV, Jakarta: Bumi Aksara, 2009.

MD, Moh. Mahfud. Membangun Politik Hukum, Menegakkan Konstitusi. Jakarta: PT. Rajagrafindo Persada, 2010.

Nadwi (al-), Ali Ahmad. al-Qawaid. 
Rahardjo, Sajipto. Beberapa Pemikiran Tentang Ancangan antar Disiplin dalam Pembinaan Hukum Nasional. Bandung: Sinar Baru, 1985.

------. Hukum dan Masyarakat. Bandung: Angkasa, 1984.

Ramulyo, Muhammad Idris. Asas-asas Hukum Islam: Sejarah Timbul dan Berkembangnya Hukum Islam dalam Sistem Hukum di Indonesia. Jakarta: Sinar Grafika. 1995.

Rosyadi, A. Rahmat dan H.M. Rais Ahmad. Formalisasi Syariat Islam dalam Perspektif Tata Hukum Indonesia. Bogor: Ghalia Indonesoa, 2006.

Shatibi (al-), Abu Ishaq. al-Muwafaqat fi Usul al-Shari'ah. Beirut: Dar al-Kutub al-'Ilmiyayah, II, 2002.

Sidharta. Moralis Profesi Hukum Suatu Tawaran Kerangka Berpikir. Bandung: PT Refika Aditama, 2006.

Soehartono. "Gejala Transformasi Hukum Islam dalam hukum Nasional Majalah Hukum Yustisia Fakultas Hukum Universitas Sebelas Maret, No. 64 tahun XVI, Januari_Maret 2004.

Suyuti (al-), Jalal al-Din Abd al-Rahman. al-Ashbah wa al-Naza'ir. Cet I, Beirut: Muassasah al-Kutub al-Thaqafiyyyah, 1994.

Tanya, Bernard L. Hukum dalam Ruang Sosial. Yogyakarta: Genta Publishing, 2010.

Teeri, Marchettini, dan Rosini.

http:/library.witpress.com/pages/paperinfo.asp, diakses tanggal 29 Mei 2009.

Utsman, Sabian. Dasar-Dasar Sosiologi Hukum: Makna Dialog antara Hukum \& Masyarakat. Yogyakarta: Pustaka Pelajar, 2009.

Wirawan, Sarlito. Psikologi Lingkungan. Jakarta: Grasindo, 1992. Zuhro, R. Siti, dkk. Demokrasi Lokal, Perubahan dan Kesinambungan Nilai-Nilai Budaya Politik Lokal. Yogyakarta: Ombak, 2009. 